\title{
Characterisation of natural organic matter (NOM) and its removal using cyclodextrin polyurethanes
}

\author{
TI Nkambule, RWM Krause*, BB Mamba and J Haarhoff \\ University of Johannesburg, Department of Chemical Technology, PO Box 17011, Doornfontein 2028, South Africa
}

\begin{abstract}
Natural organic matter (NOM) occurs in all natural water sources when animal and plant material breaks down. NOM in water may react with chlorine and other disinfectants to produce disinfection by-products (DBPs), many of which are either carcinogenic or mutagenic. In this study the NOM content of the raw water from the Vaalkop Water Treatment Plant (which uses both chlorination and ozonation as treatment protocols) was characterised after fractionation on ion-exchange resins. Fractionation at different $\mathrm{pH}$ values resulted in the isolation of a neutral, a basic and an acidic component of either predominantly hydrophobic or hydrophilic NOM. In addition, NOM results from 3 open water bodies in Johannesburg were evaluated in the same manner. As expected, NOM from all water sources was predominantly hydrophobic $(\sim 60 \%)$. Each of the 6 isolated NOM fractions was percolated through synthetic cyclodextrin (CD) polyurethanes to determine the extent to which the CD polymers can remove NOM from water. The hydrophobic basic fraction and the hydrophilic acid fraction were most efficiently removed ( $24 \%$ and $10 \%$, respectively). The remaining fractions were not much affected by the polymer treatment.
\end{abstract}

Keywords: cyclodextrin polyurethanes, disinfection by-products, fractionation, natural organic matter (NOM)

\section{Nomenclature}

\begin{tabular}{|c|c|}
\hline$\beta-C D$ & $=$ beta cyclodextrin \\
\hline $\mathrm{CD}$ & $=$ cyclodextrin \\
\hline BSH & $=$ Braamfontein Dam \\
\hline CDK & $=$ Coronation Dam \\
\hline DBP & $=$ disinfection by-product \\
\hline FLR & $=$ Florida Lake \\
\hline GAC & $=$ granular activated carbon \\
\hline HAA & $=$ haloacetic acid \\
\hline HMDI- $\beta$-CD & $\begin{array}{l}=\text { polyurethane made by co-polymerising } \beta-\mathrm{CD} \\
\text { and hexamethylene diisocyanate }\end{array}$ \\
\hline HроА & $=$ hydrophobic acid fraction \\
\hline НроВ & $=$ hydrophobic base fraction \\
\hline HpoN & $=$ hydrophobic neutral fraction \\
\hline HpiA & $=$ hydrophilic acid fraction \\
\hline НpiB & $=$ hydrophilic base fraction \\
\hline HpiN & $=$ hydrophilic neutral fraction \\
\hline HS & $\begin{aligned}= & \text { humic substances (a generally hydrophobic } \\
& \text { fraction of NOM) }\end{aligned}$ \\
\hline КHP & $=$ potassium hydrogen phthalate \\
\hline $\begin{array}{l}\text { DST/ } \\
\text { Mintek NIC }\end{array}$ & $\begin{aligned}= & \text { Nanotechnology Innovation Centre } \\
& - \text { Water Platform }\end{aligned}$ \\
\hline NOM & $=$ natural organic matter \\
\hline oligomers & $=$ short polymers (usually $<10$ monomers) \\
\hline $\mathrm{ppb}$ & $=$ parts-per-billion $($ weight $/$ weight i.e. $\mathrm{mg} / \mathrm{kg}$ ) \\
\hline SUVA & $=$ specific ultraviolet absorbance \\
\hline ГНМ & $=$ trihalomethane \\
\hline
\end{tabular}

This paper was originally presented at the 2008 Water Institute of Southern Africa (WISA) Biennial Conference, Sun City, South Africa, 18-22 May 2008.

* To whom all correspondence should be addressed.

III +27115596152; fax: +27115596425 ; e-mail: rkrause@uj.ac.za

\section{Introduction}

Natural organic matter (NOM) present in most water bodies may react with chlorine or other disinfectants to produce disinfection by-products (DBPs), many of which are either carcinogenic or mutagenic (Xie 2003). For example, haloacetic acids (HAAs), a DBP component, are considered harmful to human health and have diverse toxicological effects, including reproductive and developmental effects, in laboratory animals (Kanokkantapong, 2006). In addition NOM can cause problems of membrane fouling, aesthetically displeasing flavour and malodour, and NOM has even been implicated in the corrosion of turbines and engineering systems (McDonald, 2004). An understanding of NOM in water and its removal is therefore important for human health and in industrial processes.

NOM occurs in all water sources when animal and plant material breaks down. Since this material is different worldwide, so too is the NOM present in each body of water. NOM can be broadly categorised into humic substances (HS), microbial by-products and colloidal natural organic matter, depending on their source and structure.

Humic substances are generally the hydrophobic fraction of NOM and exhibit relatively high specific ultraviolet absorbance (SUVA) values as they usually contain relatively large proportions of aromatic moieties (Chen et al., 2002). Secondly, microbial by-products are composed of acids, with relatively high charge density, polysaccharides, amino sugars and proteins (Vanboon et al., 2005). Finally, colloidal natural organic matter contains relatively polar amino sugars and may exhibit high membrane fouling potential due to its neutrality.

Granular activated carbon (GAC) is widely used to remove organic matter from water, but it often fails to remove these to levels as low as parts-per-billion (ppb) (McDonald et al., 2004). Ozonation, often used in combination with other treatment processes, should lead to the degradation of NOM and formation of low molecular weight compounds (Karnik et al., 2005). These small fragments should be better adsorbed by GAC; however, 
when not well adsorbed on GAC they tend to be more difficult to remove due to their mobility and generally increased polarity (De Wuilloud et al., 2003).

We have previously reported on the use of cyclodextrin polyurethanes for the generation of ultra-pure water in the power industry (Mamba et al., 2008) mainly through the removal of some of these small organic fragments. It is therefore anticipated that some of the NOM and the ozonation fragments, being similar to heat-generated fragments, will be removed efficiently by the use of water-insoluble cyclodextrin polyurethanes.

To better understand the mechanism of NOM removal from water, it is necessary to understand the chemistry of NOM. In addition, this information may allow us to tailor the $\beta$-CD polyurethane adsorbents, based on our comprehension of the fundamental interactions of these molecules. Ultimately this should lead to better tailor-made solutions for the treatment of contaminated water. NOM, which is usually found in drinking water at concentration levels between 2 and $15 \mathrm{mg} / \ell$ (Hepplewhite et al., 2004), can be fractionated or separated into 3 hydrophobic and 3 hydrophilic fractions using suitable ion-exchange resins. The hydrophobic fractions contain mostly humic and fulvic acids whereas the hydrophilic fractions comprise low molecular weight carbohydrates, proteins and amino acids. This fractionation will allow for the evaluation of the extent with which each organic fraction present in the water sample can be effectively removed by the $\mathrm{CD}$ polymers, and hence allow for optimisation of adsorbents.

The synthesis of cyclodextrin polyurethanes has previously been reported (Mhlanga et al., 2007). These polymers demonstrate a good capacity to remove a wide range of organic contaminants present in water at concentration levels of $\mathrm{ng} / \ell$ (Mhlanga et al., 2007).

The aim of this work is to determine the different organic fractions of NOM in 'raw water' samples from a water treatment plant (Vaalkop) and 3 open water bodies in Johannesburg, and then to apply water-insoluble cyclodextrin polyurethanes in the removal of these NOM fractions from water.

\section{Materials and methods}

\section{Sample collection and preservation}

Water samples from the Vaalkop Water Treatment Plant and from 3 dams (Coronation, Braamfontein and Florida Lake) in Johannesburg were collected. At the Vaalkop Water Treatment Plant samples were collected before and after ozonation for the evaluation of the effect of ozone on the NOM present in water. All samples were filtered through a $0.45 \mu \mathrm{m}$ cellulose filter paper and stored in the refrigerator at $4^{\circ} \mathrm{C}$ for not more than $48 \mathrm{~h}$ before analysis. Two litres of each sample were then fractionated over ion-exchange resins according to the method by Marhaba et al., (2003).

To evaluate the removal of NOM by the cyclodextrin polymers, each fraction was treated with hexamethylene diisocyanate co-polymerised with beta-cyclodextrin (HMDI- $\beta$-CD) polymer.

\section{Fractionation procedure}

Fractionation of the NOM was performed using 3 types of ionexchange resins, namely XAD-7HP, Diaion-WA-10, and Dowex (B) 88, following the procedure described by Marhaba et al., (2003). The result is that the organic matter was divided into 6 fractions, namely; hydrophobic acid (HpoA), hydrophobic base

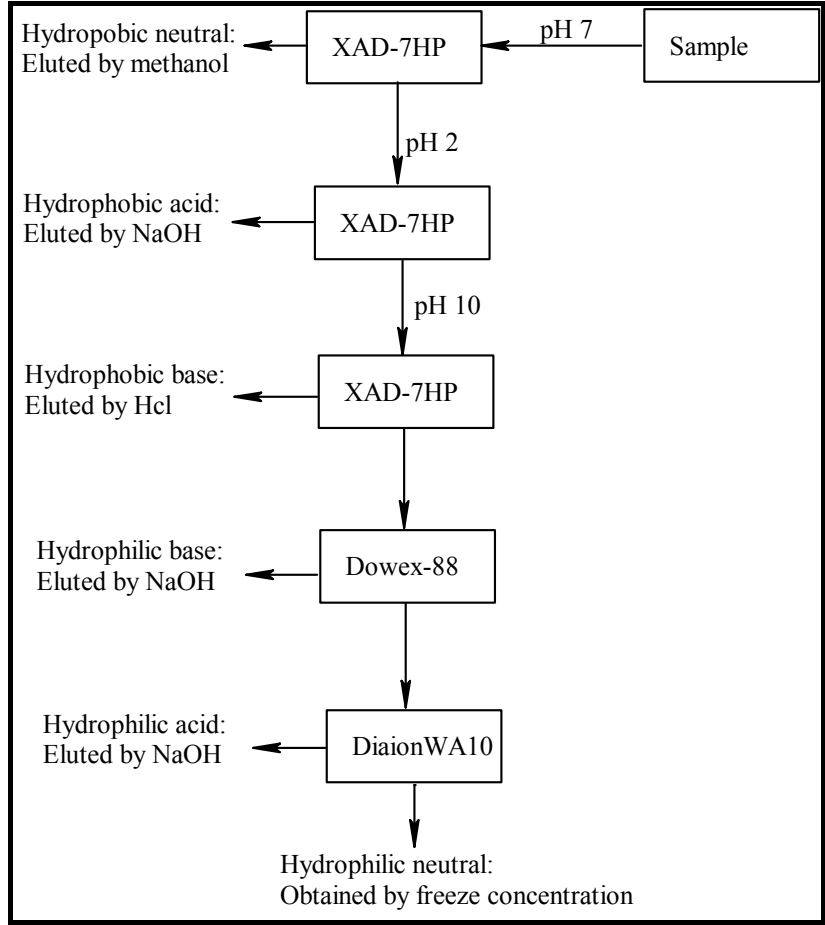

Figure 1

Fractionation method

(HpoB), hydrophobic neutral (HpoN), hydrophilic acid (HpiA), hydrophilic base (HpiB) and hydrophilic neutral (HpiN). The fractionation procedure is illustrated in Fig. 1.

\section{Organic carbon analysis}

For the purposes of this study, the dissolved organic carbon (DOC) was used as an indicator for the organic content in the water samples. DOC is that fraction of organic matter passing through a $0.45 \mu \mathrm{m}$ filter paper (i.e. it excludes suspended organic matter). The DOC of each NOM fraction was measured with a total organic carbon (TOC) analyzer (Tekmar Dormann Apollo 9000). Standards of $0,1,2,5$, and $10 \mathrm{mg} / \ell$ of total carbon were prepared with potassium hydrogen phthalate (KHP), using ultrapure water for all dilutions. At least 3 replicates of each measurement were carried out and more replicates performed where the variation between each measurement exceeded $5 \%$.

\section{Ultraviolet (UV) visible spectroscopic analysis}

The water samples were also analyzed on a UV-Vis spectrophotometer at a wavelength of $254 \mathrm{~nm}$, as the absorption at this wavelength has been reported to represent the aromatic character of the organic species. UV-254 was measured with a Cary-50 UV spectrophotometer with a $1 \mathrm{~cm}$ quartz cell.

\section{Passage of each NOM fraction through polymer}

The synthesised polymer was first cleaned to remove un-reacted cyclodextrin and synthesis solvents that could interfere with TOC measurements. This was done by first heating the polymer for an hour in an oil bath at $150^{\circ} \mathrm{C}$ under vacuum. It was then cooled to room temperature, loaded into empty solid phase extraction (SPE) cartridges, and washed with de-ionised water until the TOC reading of the filtrate was less than $0.5 \mathrm{mg} / \ell$ of 


\begin{tabular}{|c|c|c|c|c|}
\hline \multicolumn{5}{|c|}{ TABLE 1 } \\
\hline Raw water characterisation of samples from 3 water reservoirs around Johannesburg \\
\hline Sample name & TOC $(\mathbf{m g} / \mathbf{l})$ & $\begin{array}{c}\text { SUVA } \\
(\mathbf{\ell} / \mathbf{m g} \cdot \mathbf{m})\end{array}$ & $\begin{array}{c}\text { Turbidity } \\
\text { (NTU) }\end{array}$ & pH \\
\hline BSH & 4.38 & 4.22 & 2.28 & 7.76 \\
\hline CDK & 4.91 & 5.12 & 5.93 & 7.72 \\
\hline FLR & 6.46 & 2.98 & 2.97 & 7.60 \\
\hline
\end{tabular}

Note: $B S H=$ Braamfontein Dam, $C D K=$ Coronation Dam, and FLR = Florida Lake

\begin{tabular}{|c|c|c|c|c|c|c|c|c|}
\hline \multicolumn{7}{|c|}{ Organic fractions in the raw water } \\
\hline Sample & $\begin{array}{c}\text { Raw water } \\
(\mathbf{m g} / \mathbf{\ell})\end{array}$ & $\begin{array}{c}\text { HpoB } \\
(\mathbf{m g} / \mathbf{\ell})\end{array}$ & $\begin{array}{c}\mathrm{HpoA} \\
(\mathbf{m g} / \mathbf{\ell})\end{array}$ & $\begin{array}{c}\mathrm{HpoN} \\
(\mathbf{m g} / \mathbf{\ell})\end{array}$ & $\begin{array}{c}\text { HpiB } \\
(\mathbf{m g} / \mathbf{\ell})\end{array}$ & $\begin{array}{c}\text { HpiA } \\
(\mathbf{m g} / \mathbf{\ell})\end{array}$ & $\begin{array}{c}\text { HN } \\
(\mathbf{m g} / \mathbf{\ell})\end{array}$ & $\begin{array}{c}\% \\
\text { Surplus }\end{array}$ \\
\hline CDK & 4.91 & 0.12 & 0.74 & 0.54 & 1.12 & 1.45 & 1.10 & +3.3 \\
\hline BSH & 4.38 & 0.23 & 1.89 & 0.57 & 1.05 & 0.47 & 1.02 & +19.4 \\
\hline FLR & 6.46 & 0.53 & 2.12 & 0.64 & 1.49 & 0.72 & 1.24 & +4.3 \\
\hline
\end{tabular}

\begin{tabular}{|c|c|c|c|c|c|c|c|c|c|}
\hline \multicolumn{10}{|c|}{$\begin{array}{c}\text { TABLE } 3 \\
\text { Characteristics and organic fractions in the source water from Vaalkop Water Treatment Plant }\end{array}$} \\
\hline $\begin{array}{l}\text { Raw water } \\
\text { (mg/l) }\end{array}$ & $\begin{array}{l}\text { HpoB } \\
(\mathrm{mg} / \ell)\end{array}$ & $\begin{array}{l}\text { HpoA } \\
(\mathrm{mg} / \ell)\end{array}$ & $\begin{array}{l}\text { HpoN } \\
(\mathrm{mg} / \ell)\end{array}$ & $\begin{array}{c}\mathrm{HpiB} \\
(\mathrm{mg} / \ell)\end{array}$ & $\begin{array}{l}\mathrm{HpiA} \\
(\mathrm{mg} / \ell)\end{array}$ & $\begin{array}{c}\mathrm{HpiN} \\
(\mathrm{mg} / \ell)\end{array}$ & $\%$ surplus & $\begin{array}{c}\text { SUVA } \\
{[\ell /(m g \cdot m)]}\end{array}$ & $\mathrm{pH}$ \\
\hline 12.6 & 2.91 & 2.66 & 2.18 & 1.06 & 0.78 & 4.23 & +12.7 & 2.96 & 7.8 \\
\hline
\end{tabular}

total carbon. The isolated NOM fractions were then treated with the polymer by passing $30 \mathrm{~cm}^{3}$ of each organic fraction through the polymer at a filtration rate of $10 \mathrm{~cm}^{3} / \mathrm{min}$. Filtration was enhanced by the use of a vacuum pump. The polymer-treated water was then analyzed again for its carbon content using the TOC analyzer to determine the per cent carbon absorbed by the polymer.

\section{Results and discussion}

\section{Fractionation of organic species}

The dissolved organic carbon (DOC) was used as an indicator for the organic content in the water samples. Details of the average mass balance and some chemical parameters of the raw water from the reservoirs around Johannesburg are summarised in Table 1 and Table 2 while those from the Vaalkop Water Treatment Plant are summarised in Table 3.

The specific UV absorbance (SUVA) was used as an indication of the amount of humic substances versus non-humic substances in the water samples. The SUVA characterisation, results from Table 1, indicates that sample CDK and BSH are composed mainly of humic substances while FLR consists mainly of nonhumic substances. SUVA results as shown in Table 3, on the other hand, imply that the raw water from Vaalkop is composed mainly of humic substances. The infrared spectra in Fig. 1 display the different functional groups associated with the NOM in raw water.

The mass balance summarised in Table 2 and Table 3 indicates a percentage surplus which meant that the quantity of the 6 organic fractions exceeded the total amount of the initial TOC. This was due to organics released from the resin during elution and a smaller percentage due to organics in the eluants used. It was found that organics released by the resin were at times as high as $0.5 \mathrm{mg} / \ell$. This resulted in a weight surplus in the resulting organic fractions.

These data (summarised in Table 2) indicate that all the water samples were composed of mostly hydrophilic fractions, namely

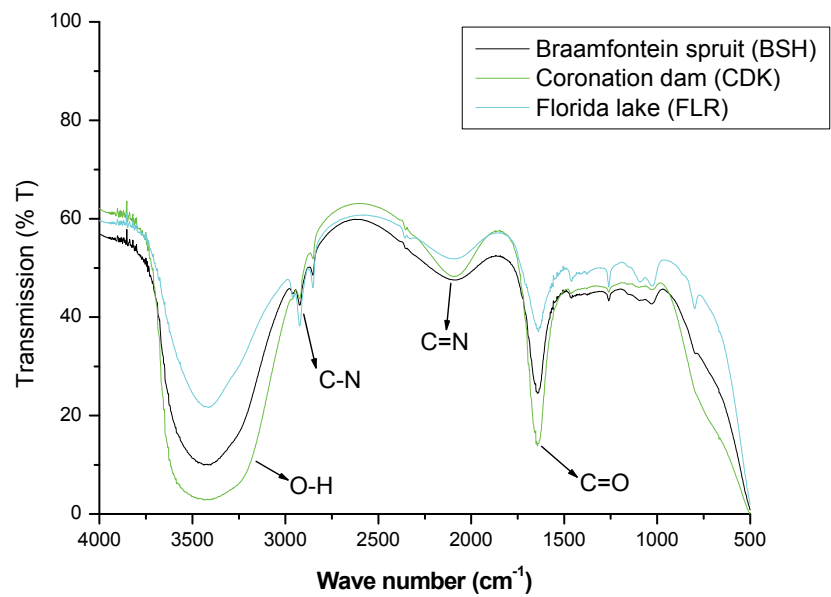

Figure 2

An IR spectrum displaying the functional groups mainly associated with the NOM in raw water

$71.8 \%, 54.6 \%$ and $51.9 \%$ for CDK, BSH and FLR, respectively. The relatively high percentage of the hydrophilic substances as compared to the hydrophobic substance suggests a contamination of the water source.

Similar to the open water sources around Johannesburg, data from the Vaalkop treatment plant (summarised in Table 3) indicates that the hydrophobic fractions are more abundant than the hydrophilic organic fractions; $56.1 \%$ and $43.9 \%$, respectively.

These findings are in agreement with accepted knowledge that hydrophobic substances would constitute a larger fraction than the hydrophilic fractions in natural water sources.

\section{Passage through $\beta$-HMDI CD polymer}

Only the samples from the Vaalkop Water Treatment Plant were passed through the polymer for this part of the study. Also, although samples were taken both before and after ozone treat- 


\begin{tabular}{|c|c|c|c|}
\hline \multicolumn{4}{|c|}{$\begin{array}{c}\text { TABLE } 4 \\
\begin{array}{c}\text { Percentage absorption of each NOM fraction after } \\
\text { passage through polymer }\end{array}\end{array}$} \\
\hline $\begin{array}{c}\text { NOM } \\
\text { fraction }\end{array}$ & $\begin{array}{c}\text { TOC before } \\
\text { passing through } \\
\text { polymer (mg/l) }\end{array}$ & $\begin{array}{c}\text { TOC after } \\
\text { passing through } \\
\text { polymer (mg/e) }\end{array}$ & $\begin{array}{c}\% \\
\text { absorbed }\end{array}$ \\
\hline НроВ & 2.91 & 2.21 & 24.1 \\
\hline НроА & 2.66 & 2.52 & 5.26 \\
\hline HpoN & 2.18 & 2.18 & 0 \\
\hline HpiB & 1.06 & 1.05 & 0.9 \\
\hline НріА & 0.78 & 0.70 & 10.3 \\
\hline HpiN & 4.23 & 4.20 & 0.71 \\
\hline
\end{tabular}

ment at the plant, it was later discovered that the ozone generator at the plant was malfunctioning, and there was no change in the relative proportions of the 6 fractions.

The data presented in Table 4 show that the percentage NOM absorbed by the polymer was not very high. The hydrophobic fractions were generally better adsorbed on the polymer than the hydrophilic fractions, with almost a quarter of the hydrophobic basic fraction (HpoB) being removed. This was followed by the hydrophilic acidic (HpiA) fraction with $10.3 \%$ removal. The hydrophobic neutral was the least absorbed fraction with $0 \%$ absorbance on the polymer.

\section{Conclusion}

NOM present in 3 natural water bodies and 1 treatment plant in South Africa was characterised by fractionation on ion-exchange resins. As expected in an urban environment, the hydrophobic fractions from both the reservoirs around Johannesburg and the Vaalkop Water Treatment Plant was composed mainly of humic substances, apart from the water from Florida Lake (FLR), which is composed mainly of non-humic substances. The extent to which each of the 6 NOM organic fractions could be removed by a synthetic $\mathrm{CD}$ polymer was evaluated to obtain a base-line for future research. Although the polymer showed a relatively low potential for removing the NOM fractions from the source water, the hydrophobic basic fraction showed an encouraging $24 \%$ removal. Future work involves pre-treating the samples with different ozone dosages in order to break down the NOM. This post-ozone treated water will then be passed through the cyclodextrin polymers to evaluate the efficiency of this combined removal process.

\section{Acknowledgements}

The authors are grateful for funding from the National Research Foundation, ESKOM's Tertiary Support Program (TESP), the University of Johannesburg, and the DST/Mintek NIC Water Platform.

\section{References}

CHEN J, GU B, LEBOEUF E, PAN H and DAI S (2002) Spectroscopic characterization of the structural and functional properties of natural organic matter fractions. Chemosphere 48 59-68.

DE WUILLOUD JC, SADI BB and CARUSO JA (2003) Trace humic and fulvic acid determination in natural water by cloud point extraction/pre-concentration using non-ionic and cationic surfactants with FI-UV detection. The Analyst 128 453-458.

HEPPLEWHITE C, NEWCOMBE G and KNAPPE DRU (2004) NOM and MIB, who wins in the competition for activated carbon adsorption sites? Water Sci. Technol. 49 257-267.

KANOKKANTAPONG V, MARHABA TF, PAVASANT P and PANYAPINYOPHOL B (2006) Characterization of haloacetic acid precursors from source waters. J. Environ. Manage. 80 214-221.

KARNIK BS, DAVIES SH, BAUMANN MJ and MASTEN SJ(2005) The effects of combined ozonation and filtration on disinfection byproduct formation. Water Res. 39 2839-2850.

MARHABA TF, PU Y and BENGRAINE K (2003) Modified dissolved organic matter fractionation technique for natural water. J. Hazard. Mater. B101 43-53.

MAMBA BB, KRAUSE RW, MALEFETSE TJ, GERICKE G and SITHOLE SP (2008) Cyclodextrin nanosponges in the removal of organic matter to produce water for power generation. Water SA 34 (5) 657-661 http://www.wrc.org.za/downloads/watersa/2008/ October/2271.pdf

McDONALD S, BISHOP AG, PRENZLER PD and ROBARDS K (2004) Analytical chemistry of freshwater humic substances. Anal. Chim. Acta 527 105-124.

MHLANGA SD, MAMBA BB, KRAUSE RW and MALEFETSE TJ (2007) Removal of organic contaminants from water using nanosponges cyclodextrin polyurethanes. J. Chem. Technol. Biotechnol. 82 382-388.

VANBOON GW and DUFFY SJ (2005) Environmental Chemistry: $A$ Global Perspective ( $2^{\text {nd }}$ edn.). Oxford University Press, UK. 257320.

XIE YF (2003) Disinfection By-Products in Drinking Water. Lewis publishers, Boca Raton, USA. 8-15. 